\title{
Pemberdayaan Masyarakat pada Pelestarian Situs Bangkai Kapal "USS Liberty", Tulamben, Bali
}

\section{Sofwan Noerwidi}

Keywords: community involvement, cultural resource management, underwater heritage, conservation, protection

\section{How to Cite:}

Noerwidi, S. (2007). Pemberdayaan Masyarakat pada Pelestarian Situs Bangkai Kapal "USS Liberty", Tulamben, Bali. Berkala Arkeologi, 27(1), 84-97. https://doi.org/10.30883/jba.v27i1.944

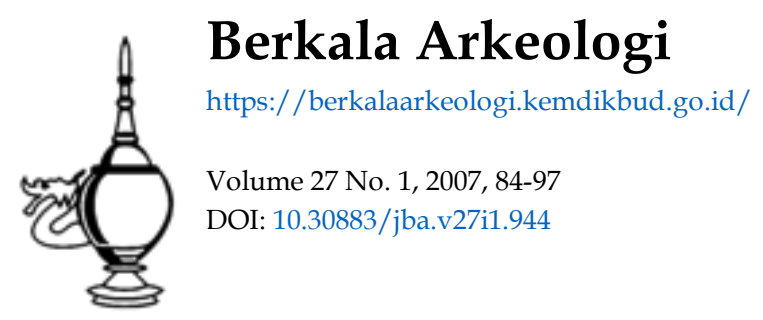

\section{(c) (1) (2)(2)}

This work is licensed under a Creative Commons Attribution-NonCommercial-ShareAlike 4.0 International License. 


\title{
Pemberdayaan Masyarakat pada Pelestarian Situs Bangkai Kapal "USS Liberty", \\ Tulamben, Bali
}

\author{
Sofwan Noerwidi \\ (Balai Arkeologi Yogyakarta)
}

\begin{abstract}
Abstrak
Indonesia sebagai negara maritim terbesar di dunia, diperkirakan memiliki 3000 situs yang mengandung sumberdaya arkeologi bawah air. Namun sayangnya, potensi yang besar tersebut belum dikelola (penelitian dan pelestariannya) dengan optimal. Berbagai konflik kepentingan dalam pengelolaan sumberdaya arkeologi bawah air menimbulkan pemikiran baru dalam visi pelestarian. Oleh karena itu, perlu dikembangkan pendekatan alternatif yang lebih dapat mengakomodasi berbagai kepentingan masyarakat lokal. Salah satu model pendekatan yang berorientasi pada masyarakat lokal adalah model pemberdayaan masyarakat. Pemberdayaan masyarakat lokal sekitar situs arkeologis dapat diwujudkan dalam tiga aspek pemberdayaan, yaitu: pemberdayaan dalam bidang a) sosial-budaya, b) politik, dan c) ekonomi.
\end{abstract}

\section{Sekilas Arkeologi Bawah Air Indonesia}

Perhatian pemerintah Indonesia terhadap arkeologi bawah air semakin besar sejak tahun 2005, seiring dengan dibentuknya Direktorat Peninggalan Bawah Air (Direktorat PBA) di bawah Direktorat Jenderal Kebudayaan, Departemen Kebudayaan dan Pariwisata. Pada masa sebelumnya, kegiatan arkeologi bawah air Indonesia mengalami pasang surut. Perhatian awal terhadap arkeologi bawah air sudah dimulai pada tahun 1980-an, ketika sejumlah arkeolog dikirim untuk mengikuti pelatihan arkeologi bawah air di Thailand dalam program SPAFA yang diikuti oleh beberapa negara ASEAN. Kemudian, beberapa peserta yang telah mengikuti pelatihan tersebut dilibatkan dalam kegiatan penyelamatan arkeologi bawah air pada tahun 
1983 di perairan Riau. Kegiatan ini merupakan kerja sama antara Direktorat Perlindungan dan Pembinaan Peninggalan Sejarah dan Purbakala, Angkatan Laut dan dengan pihak swasta yang memperoleh ijin untuk melakukan kegiatan penyelaman dan pengangkatan benda berharga. Sayangnya pada kegiatan tersebut terjadi sebuah insiden, yang menyebabkan salah seorang arkeolog mengalami kecelakaan. Ruparupanya trauma atas kejadian tersebut, menyebabkan beberapa pengambil keputusan menganggap bahwa kegiatan arkeologi bawah air penuh dengan resiko dan bahaya. Semenjak itu arkeologi bawah air Indonesia tenggelam, tanpa bekas.

Sepanjang tahun 1986 sampai dengan tahun 2000 begitu marak kegiatan pengangkatan benda berharga asal muatan kapal tenggelam yang dikenal dengan istilah Sunken Treasure. Bahkan hampir sulit dibedakan antara yang legal dan ilegal, karena hanya dengan berbekal surat sakti dari seorang pejabat tinggi maka kegiatan tersebut dapat berlangsung dengan melenggang, tanpa diketahui benda apa yang berhasil diangkat, termasuk bagi hasilnya untuk kas negara.. Pencurian ini terkadang baru diketahui tatkala telah terjadi lelang benda kuno di sebuah negara tertentu yang ternyata diperoleh dari bangkai kapal kuno di Indonesia. Contoh kasus yang terkenal adalah Kapal Geldermalsen "The Nanking Cargo" dari Karang Heliputan, Kepulauan Riau yang dilelang di Belanda pada tahun 1986 dan Kapal Tek Sing dari Selat Galassa yang dilelang di Stuttgart, Jerman pada tahun 2000 (Dradjat, 2005:30-31). Kiranya masih banyak lagi kasus serupa yang berulang-ulang terjadi tanpa mampu kita mencegah dan menghentikannya. Kejadian tersebut kiranya menjadi pemicu digalakkannya kembali kegiatan arkeologi bawah air, agar Indonesia memiliki sumberdaya manusia yang mampu diandalkan dalam usaha penelitian maupun pelestarian sumberdaya arkeologi bawah air.

Arkeologi bawah air mulai kembali diwacanakan pada tahun 1999 ketika IAAI mengadakan kongres di Yogyakarta yang mendeklerasikan bahwa arkeologi bawah air harus dikembangkan di Indonesia. Dalam kegiatan DIA XIV di Makasar pada tahun 2001 diikrarkan untuk mewujudkan kekuatan nasional bagi arkeologi bawah air (Sedyawati, 2005:1). Setelah itu, pelatihan dan pendidikan arkeologi bawah air kembali digiatkan, bahkan beberapa UPT Balai Pelestarian Peninggalan Purbakala dapat menyelenggarakan 
kegiatan ini secara simultan yang dimulai dari BP 3 Makasar pada tahun 2003, BP 3 Batusangkar tahun 2004, dan BP 3 Gianyar pada tahun 2005. Bahkan pada tahun 2006, pelatihan dan pendidikan arkeologi bawah air dilakukan oleh tiga instansi secara bergantian yaitu; Direktorat PBA bekerja sama dengan BP 3 Makasar, Balar Palembang dan BP 3 Trowulan. Pada tahun 2007, Direktorat PBA juga telah menyelenggarakan pelatihan survey arkeologi bawah air di Perairan Mandeh, Sumatera Barat dan pelatihan ekskavasi bawah air di Perairan Karimunjawa di Jawa Tengah.

Hasilnya kini telah dimiliki beberapa arkeolog yang cukup mampu diandalkan dalam kegiatan penelitian maupun pelestarian sumberdaya arkeologi bawah air. Namun hal ini hanyalah salah satu upaya untuk melihat kembali bahwa sumberdaya arkeologi bawah air ternyata sangat portensial untuk dimanfaatkan dan dikembangkan. Salah satu konsep konservasi yang berkembang pada masa kini adalah pelestarian, pemanfaatan, dan lagi. 5 .

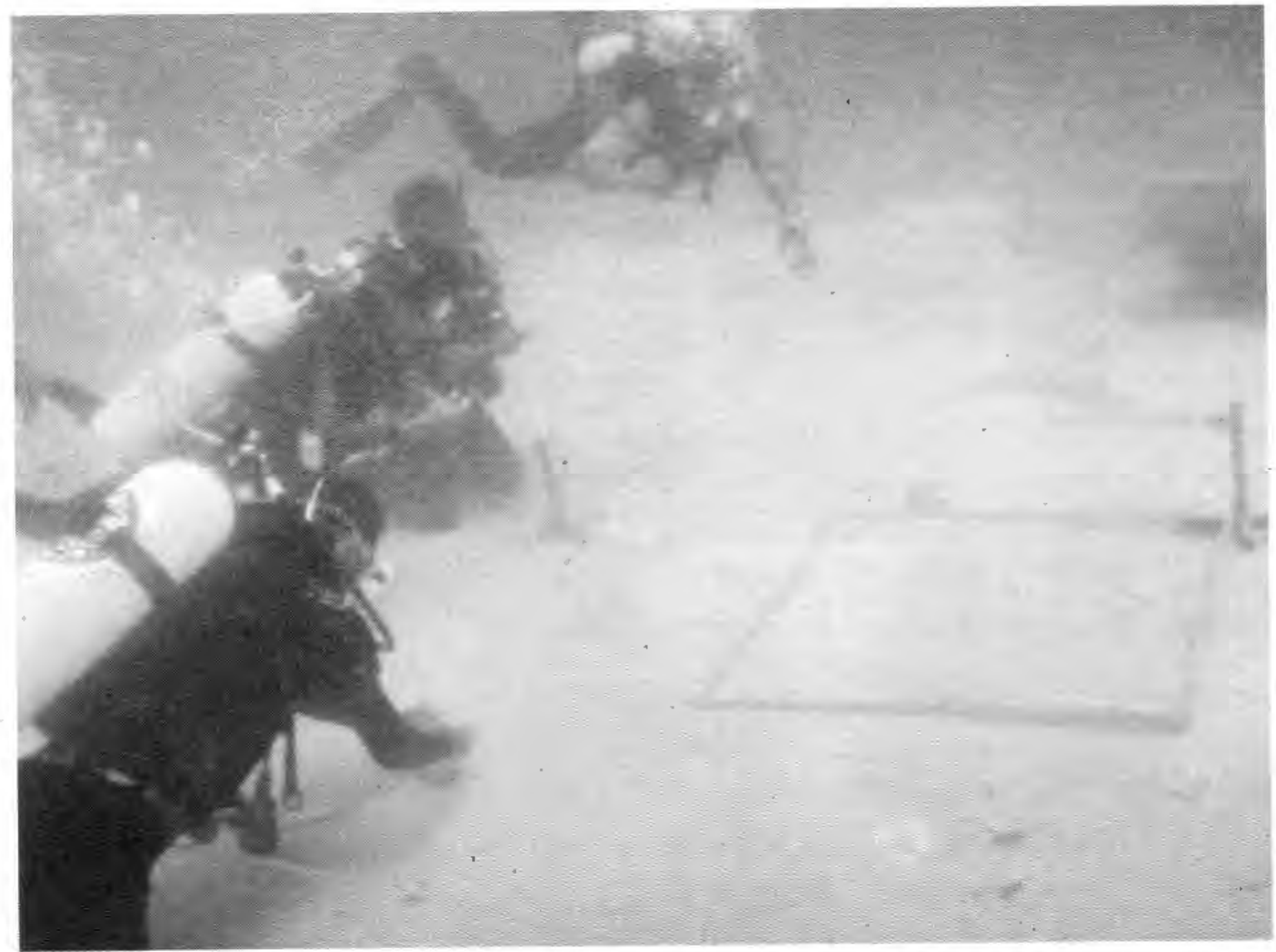

Pelatihan Ekskavasi Arkeologi Bawah Air Tahun 2007 di Perairan Karimunjawa, Jepara 
pengembangan sumberdaya arkeologi bawah air untuk kepentingan sumberdaya tersebut maupun bagi kesejahteraan masyarakat sekitar.

\section{Konsep Umum Pelestarian dan Pemanfaatan Sumberdaya Budaya Maritim Indonesia.}

Berbagai konflik kepentingan dalam pengelolaan sumberdaya yang berkembang dalam masyarakat menimbulkan pemikiran baru dalam visi pelestarian. Selama ini, kebijakan pelestarian terkesan selalu diarahkan pada upaya "tidak mengubah" atau "mengembalikan kepada keadaan semula" suatu sumberdaya budaya. Kebijakan seperti itu dirasakan terlalu kaku, cenderung picik, dan kurang dapat mengakomodasikan upaya pemanfaatannya bagi masyarakat luas. Sehingga, seolah-olah pelestarian adalah hanya untuk pelestarian itu sendiri. Namun, kini model kebijakan e tersebut sering dipermasalahkan, dan di berbagai tempat sudah mulai ditinggalkan.

Perlu disadari sepenuhnya bahwa sumberdaya budaya bersifat tidak lengkap (fragmentary), tidak terbaharui (non-renewable), terbatas (finite), dan khas (contextual): Oleh karena itu, segala upaya untuk mempertahankan nilainya harus selalu diusahakan. Namun, disadari pula bahwa upaya mempertahankan nilainya tersebut tidak selalu berarti "sekedar mengabadikan keadaan semula", tanpa memperhatikan berbagai kepentingan masyarakat luas yang beragam. Sebaliknya, pelestarian justru harus dilihat sebagai suatu upaya untuk memposisikan kembali sumberdaya budaya dalam konteks masyarakat yang ada sekarang. Sehingga, pelestarian harus dapat mengakomodasi kemungkinan perubahan, karena pelestarian harus diartikan sebagai upaya untuk memberikan makna baru bagi warisan budaya itu sendiri (Tanudirjo, 2003).

Kerangka pikir seperti ini barangkali dapat dijelaskan dengan menggunakan konsep transformasi yang dikemukan oleh M.B. Schiffer (1976). Ada dua konteks utama yang dapat menjelaskan keberadaan sumberdaya budaya, yaitu konteks sistem dan konteks arkeologi. Konteks sistem, adalah lingkungan budaya yang masih berlangsung. Dalam konteks ini, sumberdaya budaya masih berperan aktif dan dipergunakan oleh masyarakat. Konteks arkeologis, adalah lingkungan tempat sumberdaya budaya (baik yang tangible maupun yang intangible) sudah tidak digunakan 
lagi. Sumberdaya yang tidak digunakan ini seringkali menjadi rusak, hilang dan punah. Namun, tidak jarang sumberdaya budaya ini masih ada namun tidak tampak dan masih mungkin untuk ditemukan kembali.

Berdasarkan konsep transformasi tersebut, maka kegiatan pelestarian pada hakekatnya adalah upaya mempertahankan suatu sumberdaya budaya untuk tetap berada pada konteks sistem agar dapat berfungsi aktif atau dimanfaatkan oleh masyarakat. Agar tetap bertahan, sumberdaya budaya yang masih ada dalam konteks sistem mungkin saja harus dipakai ulang atau didaur ulang. Sementara itu, sumberdaya budaya yang sudah berada pada konteks arkeologis akan dapat dilestarikan jika sumberdaya tersebut dapat dimasukan kembali ke dalam konteks sistem melalui proses reklamasi maupun daur ulang. Dalam hal ini, proses reklamasi dan daur ulang adalah usaha untuk mengubah sumberdaya budaya yang sudah tidak lagi bermakna agar dapat kembali mempunyai makna atau arti penting bagi sistem budaya yang masih berlangsung. Oleh karena itu, pada dasarnya upaya pelestarian adalah upaya untuk mengembalikan sumberdaya budaya ke dalam konteks masyarakat saat ini dangan memberikan makna baru bagi sumberdaya budaya itu sendiri. Sehingga, jika tidak ada pemaknaan dan manfaat baru bagi sumberdaya budaya tersebut, maka usaha pelestarian itu sendiri akan sulit dilaksanakan atau terkadang tidak akan tercapai.

Hal yang perlu diperhatikan sebelum membahas konsep pelestarian dan pemanfaatan sumberdaya arkeologi bawah air, adalah pemahaman pada berbagai jenis sumberdaya budaya itu sendiri. Menurut Mundarjito (2003), sumberdaya budaya maritim Indonesia dapat dikelompokkan ke dalam tiga golongan yang menuntut peran serta dari tangan para ahli dengan spesifikasi kepakaran yang berbeda pula, ketiga golongan sumberdaya tersebut antara lain adalah:

a. Benda-benda arkeologis yang dilindungi oleh undang-undang tentang benda cagar budaya, meliputi: artefak, ekofak dan fitur.

b. Artefak, ekofak dan fitur yang mengandung informasi mengenai sumberdaya maritim namun belum dilindungi oleh undang-undang tentang benda cagar budaya.

c. Masyarakat lokal serta artefak etnografi, ekofak dan fitur yang berperan dalam kehidupan mereka. 
Sehubungan dengan peran serta masyarakat lokal dalam bidang arkeologi Indonesia, maka sudah saatnya dipikirkan kontribusi arkeologi bagi kehidupan masyarakat terutama dalam rangka meningkatkan kesejahteraan sosial, politik dan ekonomi masyarakat lokal. Masyarakat lokal yang secara de facto merupakan pemilik sumberdaya budaya harus diberdayakan, sehingga muncul saling ketergantungan dan hubungan timbal balik yang menguntungkan antara situs arkeologis dan masyarakat lokal. Masyarakat lokal yang diuntungkan dengan keberadaan situs arkeologis diharapkan akan muncul rasa memiliki dan berdampak positif pada kesadaran untuk melindungi dan menjaga situs tersebut. Hal yang demikian merupakan model pelestarian dan pemanfaatan sumberdaya budaya yang paling efektif dan efisien.

Untuk menciptakan hubungan yang saling menguntungkan tersebut, perlu dilakukan upaya-upaya ke arah terbentuknya kondisi yang kondusif. Dalam hal ini arkeologi harus mereposisi dirinya dari legislator menjadi mediator (fasilitator). Berperan sebagai fasilitator, arkeolog bertugas membantu masyarakat dalam proses pemaknaan atau pemanfaatan sumberdaya budaya sesuai dengan keahlian dan pengetahuannya sehingga masyarakat dapat menentukan pilihan mereka sendiri dengan tepat. Selain itu, arkeolog harus dapat membantu masyarakat atau pihak-pihak yang berbeda kepentingan menemukan resolusi di antara mereka. Karena, pada dasarnya setiap masyarakat selalu mempunyai kearifan-kearifan untuk menyelesaiakan konflik (Tanudirdjo, 2000).

Pengelolaan sumberdaya budaya di masa mendatang seharusnya memperhatikan manajemen konflik, sehingga pengelola sumberdaya budaya hendaknya memegang peran sebagai mediator dalam konflik di masyarakat. Pengelola sumberdaya budaya harus berperan aktif terlibat dalam masalah-masalah yang dihadapi masyarakat, sehingga mampu memberikan pendapat dalam diskusi dan debat publik, memberikan narasinarasi tentang warisan budaya yang penting dan relevan dengan masalah yang ada pada masa kini (Tanudirdjo, 1998).

Pengelola sumberdaya budaya juga harus kritis melihat bagaimana kepentingan masa kini mempengaruhi interpretasi masa lampau, sebagai perantara masa lampau dan masa kini, pengelola warisan budaya harus peka baik terhadap keragaman minat dan kepentingan akan masa lampau 
di mana kini maupun dampaknya terhadap kualitas sumberdaya arkeologi yang tersedia (Hodder, 1999). Oleh karena itu, arkeologi juga harus mengakomodasi beragam kepentingan dari berbagai pihak. Selain itu, pengelola sumberdaya budaya perlu juga lebih banyak melibatkan berbagai unsur masyarakat dalam pengembilan keputusan, antara lain lewat kerjasama dengan berbagai pihak dalam masyarakat. Dengan kata lain, pengelola sumberdaya budaya tidak lagi hanya memikirkan kepentingan negara, tetapi kepentingan yang beragam dari masyarakat luas.

\section{Model Pemberdayaan Masyarakat Bagi Pelestarian dan Pemanfaatan Sumberdaya Budaya Maritim Indonesia.}

Sebelum berbicara masalah pelestarian sumberdaya budaya, bagi kalangan arkeologi sendiri terlebih dahulu harus dibangun kesadaran bahwa masyarakat lokal tidak dapat diabaikan dari segala kegiatan arkeologi, serta memiliki peran yang sangat penting bagi pelestarian sumberdaya budaya. Oleh karena itu, perlu dikembangkan pendekatan alternatif terhadap kegiatan penelitian maupun pelestarian arkeologi. Pendekatan tersebut adalah pendekatan yang lebih dapat mengakomodasi kepentingan masyarakat lokal, bahkan menjadikan masyarakat lokal sebagai salah satu pusat pertimbangan utama dalam segala pengambilan keputusan dan kegiatan bidang arkeologi. Sudah saatnya kini kita beralih dari pendekatan yang hanya bersifat site oriented (orientasi pada situs) kepada pandangan yang bersifat community oriented (orientasi pada masyarakat) untuk menyesuaikan dengan situasi dan kondisi masyarakat saat ini.

Menurut Prasodjo (2000), pendekatan yang berorientasi pada masyarakat lokal dalam aplikasinya dapat diwujudkan dalam dua cara, yaitu pendekatan partisipatori dan pemberdayaan masyarakat. Pendekatan partisipatori merupakan sebuah pendekatan yang selalu melibatkan masyarakat dalam setiap langkah kerja yang dilaksanakan. Sedangkan pemberdayaan masyarakat merupakan upaya membangun landasan sosial, budaya, politik dan ekonomi yang kuat bagi masyarakat di sekitar situs arkeologis melalui kegiatan-kegiatan yang dilakukan atau dikaitkan dengan kegiatan arkeologi. Pada dasarnya pemberdayaan masyarakat lokal sekitar situs arkeologis yang dapat dilakukan oleh arkeolog dapat diwujudkan dalam tiga aspek pemberdayaan, yaitu: pemberdayaan a) sosial-budaya, b) politik, dan c) 
ekonomi. Pemberdayaan sosial-budaya masyarakat lokal dapat dicapai dengan memberdayakan kemampuan masyarakat untuk mengenali jati dirinya melalui benda cagar budaya maupun intepretasinya yang dilakukan oleh arkeolog. Pemberdayaan politik menekankan perhatian pada usaha untuk memampukan masyarakat dalam meningkatkan partisipasi masyarakat lokal dalam pengambilan kebijakan politis yang berkaitan dengan kelangsungan hidup komunitas yang bersangkutan. Sedangkan pemberdayaan dalam bidang ekonomi merupakan pemberdayaan yang secara langsung paling cepat dirasakan hasilnya oleh masyarakat lokal di sekitar situs.

\section{Lokasi Situs Bangkai Kapal "USS Liberty".}

Perairan Tulamben termasuk dalam wilayah administratif Desa Tulamben, Kecamatan Kubu, Kabupaten Karangasem, terletak di sisi timur sepanjang jalan yang menghubungkan antara Culik dan Tianyar. Perairan ini terletak di timur laut Pulau Bali, di sisi barat Selat Lombok dan termasuk dalam perairan Zona Wallacea dengan perairan yang berciri topografi terjal dan dalam. Karena letaknya yang berada di lereng Gunung Agung, kawasan Tulamben pernah menjadi daerah limpahan lahar ketika terjadi letusan tersebut pada tahun 1963. Kondisi geografis yang demikian ini menyebabkan litologi di kawasan Tulamben dan sekitarnya terdiri atas batuan andesit hasil pembekuan lava dengan ukuran besar maupun kecil. Karena kondisi hidrologinya yang sangat kering, maka kawasan ini menjadi kurang subur dan tidak dapat ditumbuhi oleh tanaman produktif. Tanaman yang cocok dan dapat berkembang hanyalah tanaman jenis palma, (seperti kelapa dan enau) yang hanya dapat tumbuh di tanah pada sela-sela batu. Lingkungan yang tidak memadai ini menyebabkan sebagian besar masyarakatnya lebih banyak bermatapencaharian sebagai nelayan, dan sebagian lagi merantau ke daerah lain yang subur untuk menjadi buruh, bahkan ada juga yang menjadi pengemis. 


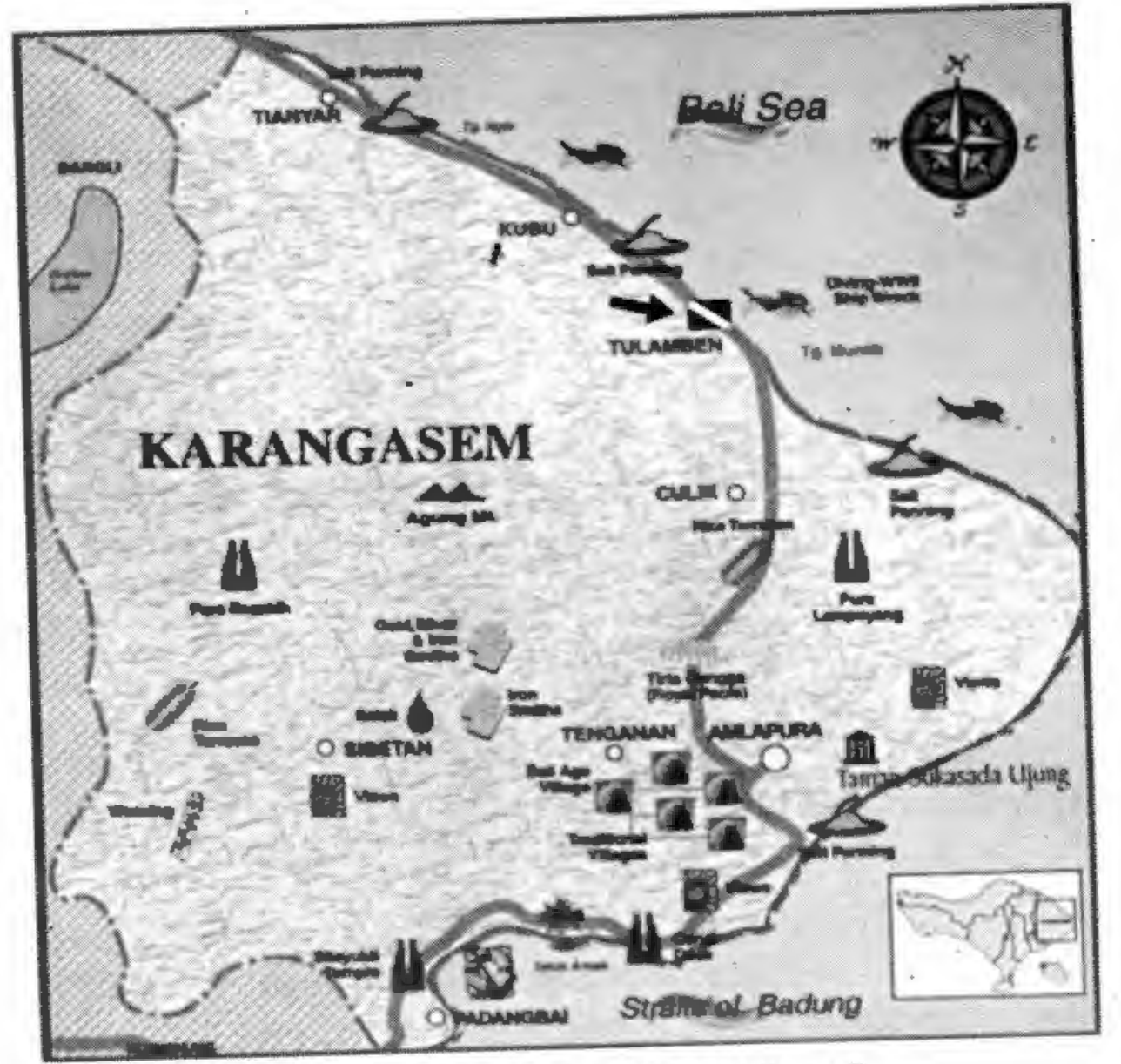

Situs Kapal Karam "USS Liberty"

Tulamben dan Potensi Pariwisata Lainnya di Kabupaten Karangasem

Di balik keganasan alam daerah timur Bali tersebut, ternyata disana juga menyimpan "harta karun" yang terpendam di dasar laut. Pada tahun 1942 saat Perang Dunia II berlangsung, terjadi musibah pada sebuah kapal dagang uap yang dipersenjatai dengan dua meriam milik Amerika Serikat yaitu "USS Liberty". Pada tanggal 11 Januari 1942, kapal tersebut sedang berlayar di sekitar 15 kilometer di sebelah barat daya perairan Selat Lombok dan membawa muatan kayu mentah dan komponen rel kereta api. Namun tiba-tiba disergap oleh kapal selam angkatan laut Jepang dan terpedo menghantam bagian lambung kapal tersebut. Kapal "USS Liberty" mengalami kerusakan mesin dan kemudian berusaha ditarik oleh "US Destroyer" menuju Pulau Bali. Namun, karena terlalu banyak kemasukan air, kapal tersebut tidak dapat berlabuh dan kemudaian karam tidak jauh (sekitar 200 meter) dari tepi pantai Pantai Tulamben sedangkan awak kapalnya berhasil dievakuasi. Setelah Belanda kalah dan menyingkir ke 


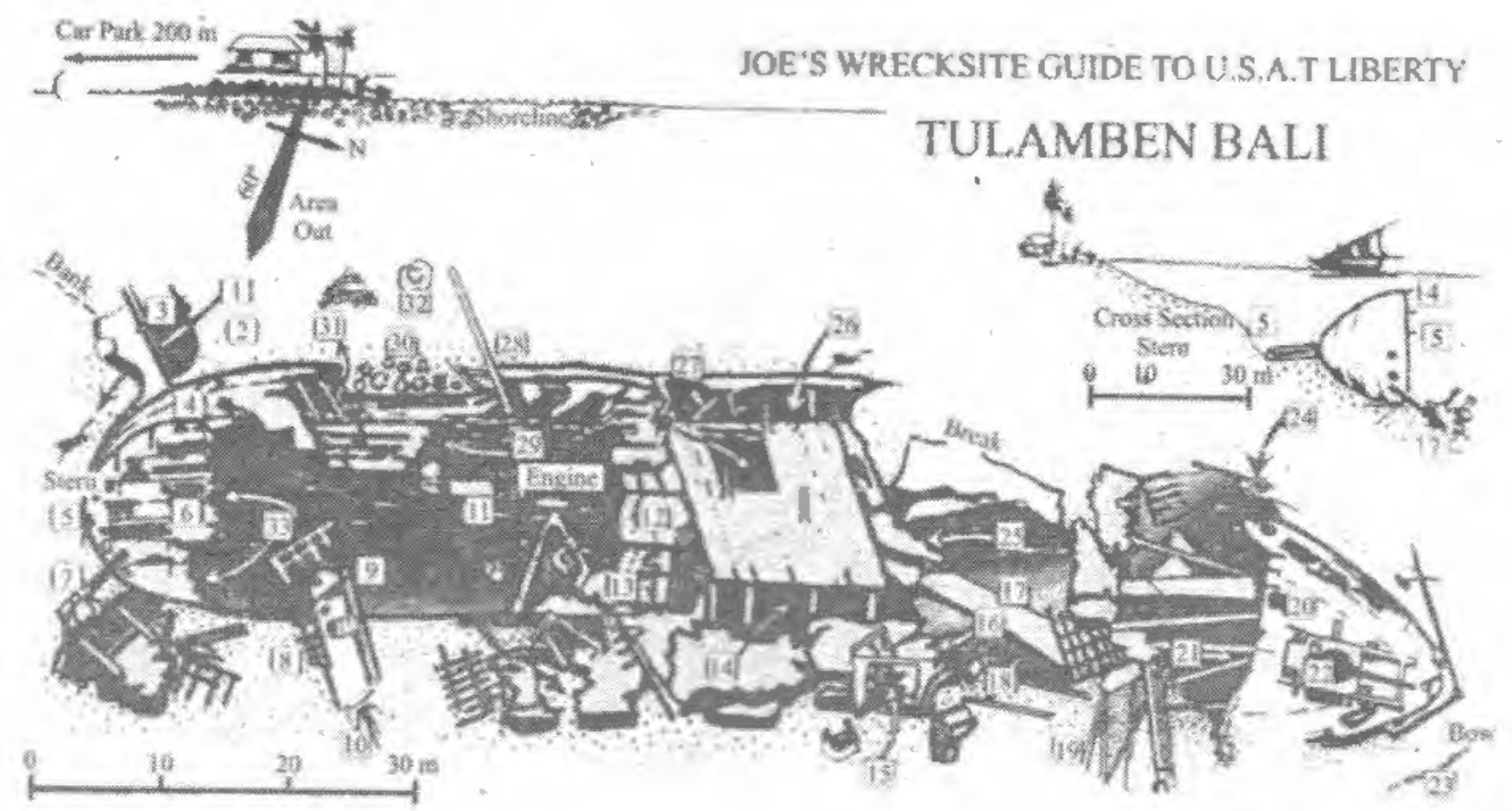

Denah Situs Bangkai Kapal "USS Liberty", Tulamben, Bali

Australia, pihak Jepang berhasil menyita "USS Liberty" beserta muatannya yang berharga.

Pada tahun 1963 ketika terjadi letusan Gunung Agung, gempa bumi menyebabkan bangkai kapal ini terbelah menjadi dua bagian besar dan semakin terdorong ke bagian laut yang agak dalam. Pada saat ini, "USS Liberty" karam dengan posisi bagian lambung miring ke arah timur dan sebagian badannya terkubur oleh lahar. Di balik peristiwa tenggelamnya "USS Liberty" tersebut, ternyata juga memberikan berkah yang luar biasa bagi masyarakat Tulamben. Pada tahun 1980-an, ketika pariwisata Bali mulai bangkit, situs ini telah menjadi salah saiu inspirasi bagi pencinta dunia selam untuk menjadikannya sebagai objek dan daya tarik pariwisata bawah air di Pulau Bali. Saat ini, situs tersebut merupakan dive spot yang paling terkenal di antara berbagai potensi wisata bawah air di Bali, dikarenakan keunikan dan keamanan yang membuat nyaman para wisatawan, bahkan memungkinkan untuk menyelam pada malam hari. Bahkan, pada musim liburan situs ini dapat dikunjungi 50 hingga 70 penyelam per hari baik siang maupun malam (night dive). 


\section{Peran Serta Masyarakat Tulamben dalam Pelestarian Situs Bangkai Kapal "USS Liberty"}

Sebagai objek dan daya tarik wisata, kawasan Tulamben kemudian berkembang menjadi kawasan industri pariwisata baru andalan wilayah Bali Timur. Sebagai objek yang telah menghasilkan devisa dan kesejahteraan bagi masyarakat di sekitarnya, masyarakat setempat merasa perlu untuk melestarikan objek ini agar tidak rusak karena ulah manusia. Masyarakat kemudian menyusun regulasi tradisional yang di Bali dikenal dengan istilah awig-awig. Dalam awig-awig tersebut antara lain mencantumkan aturan tentang;

1. Larangan tidak boleh memancing pada radius 100 meter di sekitar lokasi kapal tenggelam

2. Larangan untuk tidak mengambil ataupun memanfaatkan sisa-sisa kapal yang rusak untuk kepentingan komersial

3. Larangan untuk tidak mengganggu terumbu karang yang tumbuh dan berkembang pada dinding-dinding kapal yang akan berdampak rusaknya kapal yang telah menjadi habitat dari ekosistem laut .

4. Larangan mengambil batu-batu yang ada di sekitar kawasan pantai, dan berbagai larangan lainnya.

Pelanggaran atas ketentuan awig-awig tersebut akan dikenakan sangsi sosial-budaya dikucilkan dari lingkungannya (banjar atau desa adat), termasuk berbagai kegiatan upacara ritual keagamaan. Pada kasus ini nampak bahwa aspek politik (awig-awig) berhubungan erat dengan aspek sosial-budaya (sangsi adat).

Ketentuan-ketentuan yang muncul tersebut merupakan wujud kepedulian masyarakat Tulamben terhadap kelestarian situs bangkai kapal "USS Liberty". Karena hilang dan rusaknya kapal serta terumbu karang tersebut, maka akan menghancurkan pula seluruh sendi kehidupan ekonomi mereka sendiri. Di sini terlihat bahwa dengan pemberdayaan masyarakat, maka masyarakat lebih perduli terhadap pelestarian sumberdaya budaya. Karena dampak yang langsung dapat dirasakan oleh masyarakat Tulamben adalah, telah berkembang aspek perekonomian mereka. Di kawasan tersebut telah menjamur berbagai sarana pariwisata berupa; 


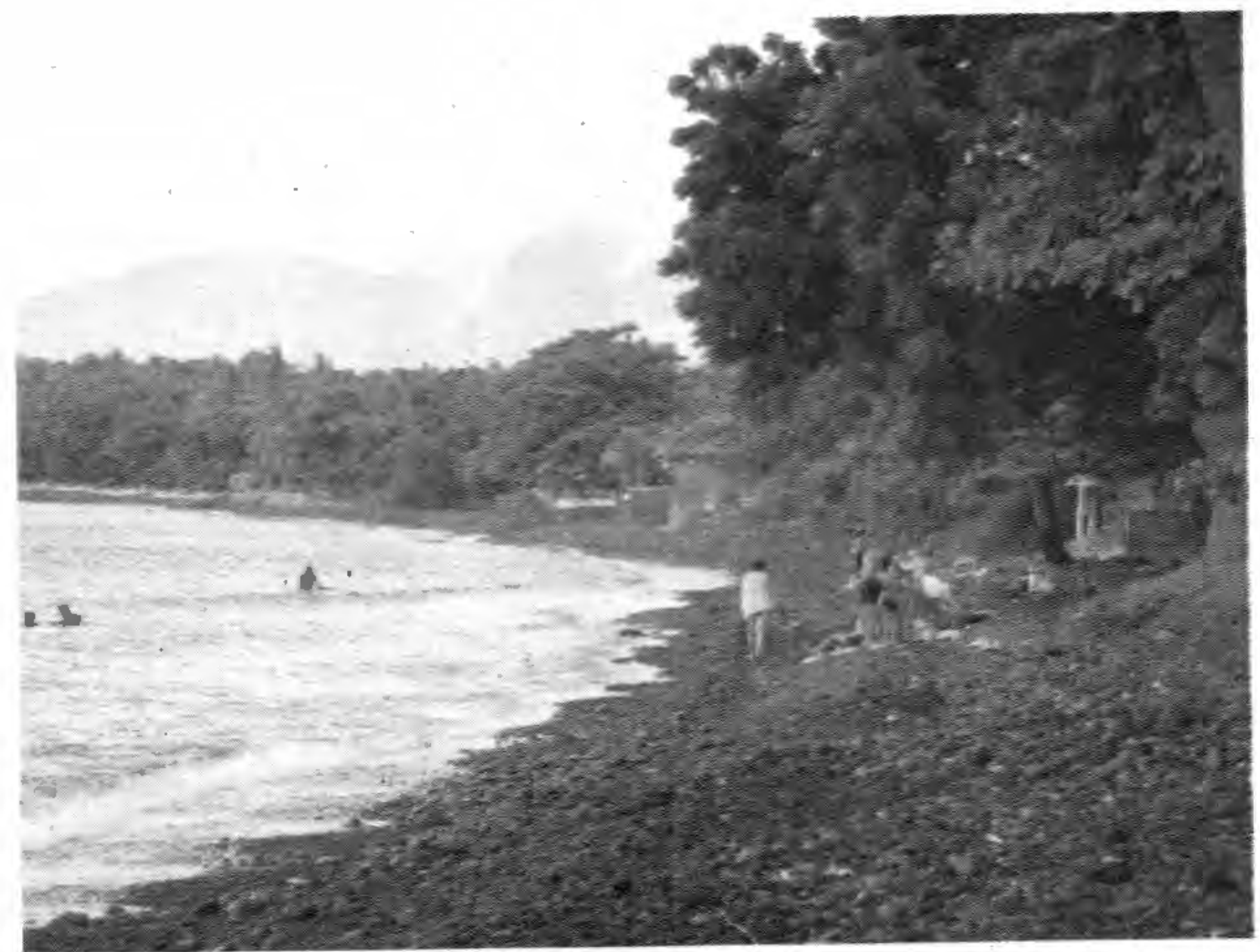

Keindahan Pantai Tulamben yang Menarik Wisatawan Mancanegara

1. Berbagai sarana penginapan, dari kelas melati hingga hotel berbintang

2. Rumah makan, restoran, dan cafe

3. Toko dan jasa penyewaan peralatan selam

4. Toko dan kios souvenir

5. Jasa telekomunikasi, wartel, warnet dan kios selluler

6. Jasa transportasi, travel, biro perjalanan dan wisata

7. Jasa penyewaan perahu, dan berbagai sarana wisata bahari lainnya Sehingga kondisi yang kondusif memungkinkan kawasan tersebut untuk selalu ramai dikunjungi wisatawan. Dengan demikian pada masyarakat sekitar situs bangkai kapal "USS Liberty" telah muncul dampak positif dalam bidang sosial-budaya, politik dan ekonomi yang saling berkaitan dan mengarah kepada keberlanjutan pelestarian sumber daya arkeologi bawah air di kawasan tersebut. 


\section{Penutup}

Masalah yang perlu dipertimbangkan dalam membangun kebijakan penanganan sumberdaya budaya maritim Indonesia antara lain adalah: tujuan arkeologi, sifat data arkeologi, penelitian yang berwawasan pelestarian, pemanfaatan dan tanggung jawabnya terhadap masyarakat luas, serta pemberdayaan masyarakat lokal. Studi kasus pelestarian swadaya (etno-konservasi) masyarakat Tulamben merupakan salah satu model yang dapat dipelajari untuk diambil manfaatnya. Di Tulamben terjadi hubungan simbiosis mutualisme yang saling menguntungkan antara masyarakat lokal dengan situs kapal karam "USS Liberty". Bagi masyarakat Tulamben, keberadaan situs kapal karam "USS Liberty" memiliki makna ekonomi, dan sosial-budaya. Masyarakat Tulamben mendapatkan keuntungan yang signifikan secara ekonomi dengan keberadaan situs kapal karam "USS Liberty", sehingga dengan sendirinya masyarakat Tulamben secara swadaya melestarikan keberadaan situs tersebut dengan perangkat sosial-budaya dan politik tradisional yang mereka miliki. Model pelestarian ini kiranya berpotensi untuk dijadikan sebagai salah satu contoh yang dapat diaplikasikan pada situs maritim lainnya dengan menyesuaikan karakter sosial masyarakat yang bersangkutan. Namun pada hakikatnya pekerjaan pelestarian dan pemanfaatan sumberdaya budaya maritim merupakan pekerjaan besar dan mahal yang menuntut partisipasi dari berbagai pihak. Sehingga dibutuhkan sebuah jaringan kerjasama antara berbagai lembaga pemerintah, masyarakat lokal, peneliti, akademisi, pelestari, lembaga swadaya masyarakat, pengusaha dan berbagai stake holders lainnya yang komprehensif dan saling bersinergi sehingga terjadi keseimbangan antara berbagai kepentingan pelestarian dan pemanfaatannya. 


\section{KEPUSTAKAAN}

Dradjat, Hari Untoro. 2005, "Penelitian dan Penyelamatan Sumberdaya Budaya Bawah Laut", dalam ed. Edi Sedyawati Eksplorasi Sumberdaya Budaya Maritim, Jakarta: Departemen Kelautan dan Perikanan dan Universitas Indonesia.

Hodder, Ian, 1999, The Archaeological Process, an Introduction. London: Routledge.

Mundarjito, 2003, "Wawasan Arkeologi Maritim", Makalah Disampaikan Dalam Lokakarya Pemanfaatan Benda Berharga Asal Muatan Kapal Tenggelam, Jakarta.

Prasodjo, Tjahjono. 2003, “Arkeologi Dan Pemberdayaan Masyarakat Lokal", Buletin Cagar Budaya, No.3, Januari 2003.

Schiffer, M.B. 1976, Behavioral Archaeology. New York Academic Press.

Sedyawati, Edi. 2005, "Kajian Maritim Aspek Sosial-Budaya Ragam dan Peluangnya" dalam ed. Edi Sedyawati Eksplorasi Sumberdaya Budaya Maritim, Jakarta: Departemen Kelautan dan Perikanan dan Universitas Indonesia.

Tanudirjo, Daud Aris. 1998, "CRM sebagai manajemen konflik". Artefak No. 19 Februari 1998.

Tanudirjo, Daud Aris. 2000, "Reposisi Arkeologi Dalam Era Global". Buletin Cagar Budaya, No.2, Juli 2000 (Suplemen).

Tanudirdjo, Daud Aris. 2003, "Warisan Budaya untuk Semua, Arah Kebijakan Pengelolaan Warisan Budaya Indonesia di Masa Mendatang", Makalah Disampaikan Dalam Kongres Kebudayaan V, Bukit Tinggi. 